\title{
CONTRIBUTING TO A REAL SOCIALIST COMMONWEALTH: MUNICIPAL SOCIALISM AND HEALTH CARE IN SHEFFIELD (1918-1930)
}

\author{
Introduction
}

The relationship between political thought and action remains as controversial as ever. Defining the connections between ideology and public policy involves a complex nexus of beliefs, pragmatism, personnel and financial realities. In 1926 Sheffield was the first major British city to elect a Labour Council. The Council's commitment to spending money on developing local services has long been recognised. However a closer scrutiny of the theories and realities of municipal socialism in Sheffield between the wars reveals a more complicated picture. Where a municipal socialist ideology could inform a commitment to develop public health services, it could simultaneously lead to a less than progressive stance over such areas such as smallpox vaccination.

The inter-war period has been heralded as the golden age of local government in Britain. A combination of national legislation and local initiative, strengthened the scope and potential of local authority health care, in fields such as maternity and child welfare, tuberculosis treatment, the school medical service, and the administration of general hospitals. The permissive nature of much of this legislation meant that there were wide variations in the level of health care provided by municipalities in Britain. In 1948 the Labour Government of the day took the decision to nationalise rather than municipalise health services. This decision dramatically reduced the role of local government in the provision of health services. There has therefore been a democratic deficit in the British NHS from its inception. This paper examines an era in the history of health care when local decision taking and policy making was at its peak. In the decades before centralisation and nationalisation took precedence, there was scope for the expression of a locally rooted municipal socialism in public policy.

The term municipal socialism is problematic and somewhat ambiguous, incorporating both a political ideology of collectivism and the more neutral notion of city government. It has generally been used to refer to two distinct periods in British history. Firstly the Fabian metropolitan based intellectual notion heralding the democratic benefits of public service provision administered by local authori- 
ties in the late nineteenth century and early years of the twentieth century, which followed the administrative developments in Birmingham. City government at this time was controlled by Liberal and Conservative Councils. The other recognised era of municipal socialism in Britain is the $1980 \mathrm{~s}$, when many major localities administered by Labour councils attempted to assert the local role in democracy and found themselves in conflict with the centralising tendencies of the Conservative government. This paper examines a different era of municipal socialism, the inter-war years in Sheffield. It takes the view that ideologies are protean, dynamic phenomena that change over time and through circumstance, and therefore constitute more complex issues, than is implied by the analysis of ideologies as a set of static "isms". The paper aims to go some way towards addressing two lacunae in British history, namely that the history of twentieth century health services before the introduction of the NHS, is an under-researched area, and secondly, that the role of ideas and ideology in twentieth century British welfare policy has also been a neglected area ${ }^{1}$. These notions are framed in a case study of the city of Sheffield. Consideration is also given to the urban variable in the formulation of a municipal socialist health policy in Sheffield.

\section{Municipal socialism: pragmatism and ideology}

Socialism, or the public ownership and control of the means of production, control and exchange was not the fundamental concern of those associated with the "gas and water municipal socialism" famously seen in Birmingham in the 1870s. Here local paternalistic leaders of bourgeoise governance consolidated powers, under the local state so that civic improvement schemes and public utilities were brought within the sphere of local government for utilitarian reasons $^{2}$. Where public utilities were run for profit in order to reduce the local taxation bill, the term municipal trading is more appropriate than any real sense of municipal socialism. In late nineteenth century Sheffield, Conservatives and Liberals were somewhat slower than their counterparts in other major cities to develop a similar sense of civic pride. Only at the closing of the nineteenth century did the local authority embark on a serious effort to municipalise key

\footnotetext{
${ }^{1}$ See Michael Freeden, The Stranger at the Feast: Ideology and Public Policy in Twentieth Century Britain, in: Twentieth Century British History 1, 1 (1990) p. 9-34. Charles WEBSTER, Conflict and Consensus: Explaining the British Health Service, in: Twentieth Century British History 1, 2 (1990) p. 115-51.

${ }^{2}$ For late nineteenth and early twentieth century Municipal Socialism in Birmingham and Glasgow see Hamish FraSER, Municipal Socialism and Social Policy, in: R. J. MORRIS, Richard RODGER (eds.), The Victorian City. A reader in British urban history 1820-1914, London, New York 1993, p. 258-280.
} 
utilities such as water, electricity and the tramways. (Gas supply in Sheffield was never municipalised and remained in private hands until nationalisation in 1948). However by the First World War and the onset of the depression, these tentative steps towards an active local government role and a municipalising philosophy were curtailed. The philosophy of the Right (following their municipalisation of the water supply, the tramways and electricity) was "thus far and no further". However a more developed sense of municipal socialism was being forged by The Labour Party in early twentieth century Sheffield. Labour stated that what the Liberals and Conservatives had done with water "we want to do with coal, milk, education and other things" $"$. Liberals in Sheffield responded to the threat of socialism at local elections by adapting their language for electioneering purposes, whilst retaining a strictly limited notion of the legitimate role for municipal action. The Liberal leader in Sheffield Sir William Clegg is quoted as stating in 1907, "... speaking for himself he was a Socialist, as every progressive man must be. But there was a great difference between his socialism and that spurious kind enunciated by Mr Keir Hardie and his followers in Sheffield. True Socialism meant the provision of those things which were necessary for the benefit and advantage of the people as a whole, and could not be adequately provided by private enterprise, and which it should be the duty of the municipality to have control of. Spurious Socialism was that which preached the confiscation of other people's goods without payment and by force - which did away with the natural ambition of individual men",

Liberals in Sheffield in the early years of the twentieth century therefore advocated a form of "municipal socialism" however they stopped short of supporting municipalisation schemes which would have impinged on the territory of "individual men" i.e. the business community. Labour on the other hand campaigned for widespread municipalisation schemes incorporating, milk supply, a municipal bank and for a while they even proposed the introduction of a municipal currency ${ }^{5}$. The very real possibility of a Labour victory in Sheffield drove the Liberal and Conservative parties to abandon their separate political identities and form in 1918, the "Citizen's Alliance". This body held office in Sheffield from 19181926. However its raison d'être was not a positive programme of active government, but an ideology predicated on a largely defensive and therefore negative stance of anti-socialism. The Citizen's Alliance was driven by a single ideology of "Economy" which saw a very limited role for local government and which stood in stark contrast to the municipalisation schemes of the Labour Party ${ }^{6}$. The

\footnotetext{
${ }^{3}$ Sheffield Co-operator, December (1927).

${ }^{4}$ Quoted in Herbert KEEBLE HAwSON, Sheffield the Growth of a City 1893-1926, Sheffield 1968, p. 291.

${ }^{5}$ Sheffield Independent, 10 December 1919.

"The "Economy" ideology of The Citizens Alliance with its intimations of financial prudence, became somewhat ironic as by the time Labour were elected in 1926 they inherited a civic deficit from the Conservative and Liberal alliance of one million pounds.
} 
ideology of "Economy" espoused by the Right entailed using the profits of municipal trading to reduce the level of local taxation, (rates) wherever possible, rather than use profits to expand local service provision.

For a large city Sheffield has an unusually large working class population and a very small middle class. As an industrial city its labour force, until well into the late twentieth century, was primarily engaged in manufacturing industry. Following the extension of the franchise in 1918 and the politicisation experienced during the 1926 General Strike, it was a Labour Party committed to active government and a form of municipal socialism that went far beyond the concept of municipal trading, that took control of the City Council in November 1926, a position they have held ever since ${ }^{7}$.

Sheffield, the fourth largest city in England, with its duel economy of cutlery and steel manufacturing, has had a strong trade union tradition. Initially its trades unions supported Liberal candidates in elections, however in the 1920 s the Sheffield Trades Council came under the control of more socialist elements. To all intents and purposes the Trades Council was the borough Labour Party as it decided which seats to contest and selected candidates. The President of the Trades Council, Ernest Rowlinson, an ex-railwayman, became the Leader of the Labour Group on the City Council and was therefore Leader of the City Council from 1926, until his death in 1941. Writing in the Labour Magazine in 1926 Rowlinson clearly stated the aim of the new administration, "we in Sheffield are hoping to make our local contribution to the development of a policy which will be a material contribution towards bringing about a real Socialist Common-

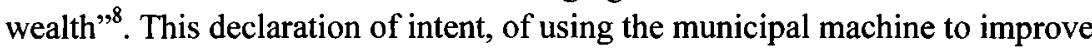
the lives of the citizens of Sheffield under a socialist philosophy, showed a movement away from trade union concerns towards a greater appreciation of the possibilities and responsibilities of the governance of a major city, where the local state could intervene in all aspects of life including health and welfare provision.

\section{Health care}

The historiography of the development of health services in Britain has tended to ignore innovations and activities at the local grass-roots level, and has focused instead on centralised events and reforms at the national level. In writing his history of the English health service in 1958, Eckstein neglected the activities of

\footnotetext{
${ }^{7}$ Labour have held a majority of seats on Sheffield City Council every year since 1926, except on three occasions: 1932,1968 and 1999.

${ }^{8}$ Ernest ROWLINSON, The Triumph of Municipal Enterprise: Why Sheffield is a Labour Stronghold, in: Labour Magazine 6, 8 (1927) p. 355.
} 
local Labour parties and focused on bureaucratic events at the centre. As national government in twentieth century Britain was dominated by the Conservative party, this approach denied any role for the Left and the Labour Party in contributing to the development of health services in Britain. The left were only seen as significant from the moment that they became part of the technocratic elite on forming the post 1945 Labour Government". Eckstein states how, "the Labour Party was certainly not in the vanguard of the agitation. It joined the team, at best in the middle of the game"10. Eckstein goes on to state that "of all the people and organizations articulately concerned with medical reform before the war the socialists were the last and, in some ways the most half-hearted in the field. The services provided by the National Health Service are very far removed from British socialism's classic image of an ideal medical system. The essence of that ideal society so just and so efficiently organised that a need for medical services simply would not arise. Illness, thought the socialists, was the product of social conditions, like unemployment or any grave social evil. It was the result of bad housing, bad nutritional standards, excessive drinking, overwork and lack of adequate sanitation. The function of a socialist society would not be to cater to disease but to abolish it" $"$.

This paper aims to show how Labour and municipal socialism in Sheffield were important to the development of health services in the 1920s and 1930s, in order to develop a more nuanced picture of Labour's role in inter war health care than the one portrayed by Eckstein. An examination of the attitudes towards health care of leading elements of the Labour movement in Sheffield in the 1920s, appears to substantiate aspects of Eckstein's claim. In the same year that Labour came to power in Sheffield there was an epidemic of the infectious disease smallpox. 700 cases were reported over the winter of 1926/1927, and all occurred in the Attercliffe area of the city which was a close mix of steelworks and workers' terraced housing. After the epidemic William Asbury the Labour Chairman of the Sheffield City Council Health Committee, published an article in the Journal of the Royal Sanitary Institute, in which he strongly condemned the practice of smallpox vaccination, a service administered by the local authority. Asbury asked: "How much longer is this fetish for vaccination to be allowed to continue? Smallpox is a filth disease and like all zymotics is amenable to sanitation. Our job is to work for a decent standard of life for the working class, place them in clean and healthy surroundings, make them fully acquainted with the laws of personal hygiene, and to the extent we do this so will all the filth diseases further decline" 12 .

${ }^{9}$ Harty ECKSTEIN, The English Health Service: Its Origins, Structure and Achievements, Cambridge, Mass. 1958.

${ }^{10}$ Ibid., p. 108.

${ }^{11}$ Ibid., p. 102.

${ }^{12}$ William ASBURY, The Case Against Vaccination, in: The Journal of the Royal Sanitary 
Asbury's attitude expresses the socialist conception of health services as noted by Eckstein, in stating that vaccination was a palliative, and a waste of resources. Rather than focusing on medical methods, Asbury believed that the council should embark on a housing scheme to remove insanitary housing and attack the root causes of disease rather than simply deal with the symptoms. In his role as the first Labour Chairman of the City Council Health Committee, Asbury expressed this same attitude in relation to other diseases such as tuberculosis. In 1928 he inserted an introduction to the Annual Report of the city's Medical Officer of Health, (itself a political act in a document that hitherto had been the sole concern of a non-political municipal employee - the Medical Officer of Health). In his introduction Asbury questioned the sense and efficacy of spending rate-payers money on removing patients suffering from tuberculosis from their homes to be treated by medical staff at the expense of the City in sanatoria, and then returning those patients on recovery to the inadequate housing conditions that had induced the disease in the first place ${ }^{13}$. Other elements of the left in Sheffield shared this environmentalist, preventative approach which championed alternatives to vaccination. The Sheffield Forward, the newspaper of the city's collective trades union body the Trades Council, warned its readership to be wary of the motives of the medical profession. It was deeply suspicious of the emerging germ theory of disease, which it believed was "thoroughly unscientific" and stated that "not until socialism is achieved will we be free from the horrors of commercialised medicine, with its vaccines and vivisection and all the loathsome practices ... in which this pseudo-scientific spirit practices on the bodies of men"14.

This degree of anti-vaccinationism expressed by the Left in Sheffield was quite unprecedented for the twentieth century. Anti-vaccinationism in late nineteenth century urban centres such as Leicester had been based around a serious disbelief in the efficacy of the procedure, and an unwillingness to use medical intervention. However in Leicester this had led to the development of an alternative strategy to deal with smallpox, one of isolation rather than vaccination ${ }^{15}$. Whereas the Chairman of the Health Committee in Sheffield was adamantly opposed to vaccination but offered no alternative strategy. Asbury's anti-vaccination stance was argued from a number perspectives, some were medical and others political or ideological. He denied that smallpox was a serious condition, and likened its virulence to that of chicken-pox ${ }^{16}$. Asbury also argued that vaccination was a dangerous practice as it ran the risk of the vaccinated being introduced to syphilis

Institute XL, VIII (1927) p. 150.

${ }^{13}$ William ASBURY, Introduction to the Annual Report of the Medical Officer of Health for Sheffield, 1928.

${ }^{14}$ Sheffield Forward, December, 1926.

${ }^{15}$ See S. M. F. FRASER, Leicester and Smallpox: The Leicester Method, in: Medical History 24 (1980) p. 315-332.

${ }^{16}$ William ASBURY, The Case Against Vaccination, in: The Journal of the Royal Sanitary Institute XL, VIII (1927) p. 151. 
and encephalitis. From an ideological standpoint he argued that local authorities had become complacent in their duty to the public, in thinking that rather than change society and spend all their energies improving social conditions, all that was needed to eradicate disease, was the application of techniques such as vaccination, which provided local authorities with the excuse not to embark on social reform programmes. Municipal socialism for Asbury in the 1920s, was therefore translated into the improvement of living conditions through house building, rather than in the provision of health services and medical treatment.

\section{Urbanization in a working class city}

In some senses then it would appear that Eckstein's view, that the Left were irrelevant to the history of health care before the NHS, is an accurate one. Preventing illness, through changing the environment was certainly at the forefront of Labour Party thinking in Sheffield in the 1920s, rather than focus on the provision of health services designed to deal with the consequences of living in a poor environment. However rather than dismiss the Left as inconsequential to the development of health policy, it is perhaps wiser to analyse the nature of municipal socialist and Labourist ideology in relation to health policy, as a part of an ideological dynamic, that changed over time. Urbanization and suburbanization provided the Left in 1920s Sheffield, with the opportunity to develop a popular ideology of municipal socialism, within a complex policy network of housing, education, employment, and health care.

Morris has suggested that "the British towns of the industrial revolution were substantially the creation of the middle class and in turn provided the theatre within which that middle class sought, extended, expressed and defended its power" $"$. Following this interpretation of the nineteenth century city as a middle class locale, Savage has argued for a more neutral interpretation of the relationship between social class and place, hence, "classes need to make places theirs ... through a process of struggle"18. For Savage, the working class in the early twentieth century "made" some cities theirs through an increasing dominance in local power structures. The critical decade in which the working class was able to establish stability in organisation, and the opportunity to consolidate bases of power, was the $1920 \mathrm{~s}$. The suburbanization and ruralization of the middle class

\footnotetext{
${ }^{17}$ R. J. MORRIS, The Middle Class and British Towns of the Industrial Revolution, 1780-1870, in: Derek Fraser, Anthony SuTClifE (eds.), The Pursuit of Urban History, London 1983, p. 286.

${ }^{18}$ Mike Savage, Urban History and Social Class: Two Paradigms, in: Urban History 20, I (1993) p. 61-77.
} 
allowed the working class to "constitute themselves at spatial scales above those of the neighbourhood alone, and gain a greater presence in the urban realm"19. For Britain the nineteenth century has been seen as the century of urbanization. David Harvey's assertion that "the twentieth century has been the century of urbanization" ${ }^{\prime 20}$, relates to worldwide patterns of settlement, where vast numbers on all continents came to live in towns and cities. However we can develop a useful interpretation of twentieth century urbanization which goes beyond its obvious epistemological roots in contrasting the percentage of people who live in rural as opposed to urban areas. Urbanization can be seen as a social process, as a phenomenon that is concerned with more than rising population totals. Events in Sheffield in the 1920s were very much concerned with the social and political opportunities offered to an urbanized working class. The consolidation of a critical mass of support for the Labour Party in Sheffield meant that a programme of municipal socialism proposed by socialists, rather than the "Economy" measures of municipal trading implemented by Liberals and Conservatives held popular appeal with the electorate in a working class city.

There was a sense in the 1920s that Sheffield was developing something of a civic mentality, a characteristic which it had noticeably lacked in the nineteenth century especially when compared to other northern industrial towns. Nineteenth century commentators noted how Sheffield resembled a village rather a large urban area ${ }^{21}$. Numerous developments in the governance of early twentieth century Sheffield, saw a movement towards urban blocs of power for the first time. Previously highly localised neighbourhood organisation had predominated. The decade saw developments in party politics, trade union organisation, the reform of poor relief and the administration of health facilities along the lines of city wide control.

The 1920s saw the Labour Party in Sheffield, extend its realm beyond its initial stronghold's in the industrial East End. Labour fought every municipal seat for the first time in 1919, and Labour representation on the City Council steadily increased until it achieved overall control in 1926. In 1920 the Sheffield Federated Trades Council, a Liberal-Labour, leaning organisation with a heritage of trade and guild protection, a body mainly concerned with the interests of workers in the "light" trades of cutlery and tool manufacture, merged with (or was taken

${ }^{19}$ Ibid., p. 76.

${ }^{20}$ David HARVEY, Contested Cities: Social Processes and Spatial Form, in: Nick JEwson, Susan MACGREGOR (eds.), Transforming Cities: Contested Governance and New Spatial Divisions, London 1997, p. 19.

${ }^{21}$ The Liberal MP A. J. Mundella noted in the mid-nineteenth century "I see a pretty state of things your municipality. Everything is mean, petty and narrow in the extreme. What a contrast to Leeds! Sheffield would do well to spend half a million on improvements. A better Town Hall might be followed by better town councillors and more public spirit." Quoted in D. E. FLETCHER, Aspects of Liberalism in Sheffield, 1849-1886, unpublished University of Sheffield Ph.D. thesis, (1972) p. 91. 
over by) its rival, Sheffield Trades and Labour Council, which was a more socialist inclined left wing organisation, concerned with workers in the "heavy" trades of steel manufacture and heavy engineering. The new trades council was therefore more left wing and dominated by the concerns of steel workers based in the industrial East End of the city, the steel corridor of the Don Valley ${ }^{22}$. In 1925 the city's two Poor Law Unions (the Sheffield Union and the Ecclesall Union) merged into one city wide body. ${ }^{23}$ In the voluntary sector Sheffield's four voluntary hospitals united in 1920 to form the Sheffield Joint Hospitals Council which organised finance for the hospitals through its workers contributory scheme, which involved representatives from the university, the local authority and the Trades Council ${ }^{24}$.

The city is often seen as an exemplar of Municipal Socialism. The local authority has been portrayed as a good landlord, employer, and provider of services, particularly in the field of housing. The type of housing built has also been notable and pressure from the Left in the shape of the "Sheffield Association for the Better Housing of the Poor" established in 1889 , well before the victory of 1926 established a principle in the city of suburban low density, semi-detached housing for the working class rather than the inner city tenements seen elsewhere $^{25}$. Once in power the Labour Party boosted the local authority's role as an employer by establishing a "direct works" department that was concerned with house building and which employed over 400 people. Other immediate reforms included a reorganisation of the Health Committee to include the Care of the Mentally Defective, an area considered by the previous administration to be separate from health care. The council also closed down the city's 166 private slaughter houses and replaced them with a single municipal abattoir. The Sheffield Forward celebrated the election of Labour in 1926 by stating "In our columns we prove by official figures that Sheffield can benefit by the elimination of profit-mongers and the substitution of Municipal Enterprise based on a realisation of social consciousness. Houses can be built cheaper by direct labour. Money can be obtained at a cheaper rate by the establishment of a Municipal Bank. Useful schemes of work at Trade Union rates of pay can be promoted" 26 . This triumphalism was also expressed by the Sheffield Labour Party in 1932, in its pamphlet Six Years of Labour Rule. Walter Greenwood stated in the preface, "this little volume shows what was actually accomplished by a Labour Council with Socialist ideals. It should prove to be an inspiration to all right minded

\footnotetext{
22 Sidney POLLARD, A History of Labour in Sheffield, Liverpool 1959, p. 265.

${ }^{23}$ B. J. ElliotT, The Last Five Years of the Sheffield Guardians, Transactions of the Hunter Archaeological Society 1977, p. 132.

${ }^{24}$ Sheffield and district association of hospital contributors, Record of the Penny in the Pound Scheme, 1919-1948, Sheffield, (1949).

${ }^{25}$ P. Dickens, S. DunCaN, M. Goodwin, F. Gray, Housing, States and Localities, London 1985 , p. 162.

${ }^{26}$ Sheffield Forward, November, 1926.
} 
people, to use every effort to secure the triumph of Socialist principles in municipal life" ${ }^{\prime 27}$. Published in 1932, the pamphlet indicated that the provision of health services was becoming a part of the municipal ideal in Sheffield.

The Health side has still further been safeguarded by a large increase in the medical service both in the clinics and in the schools. The dental staff has doubled, and others have increased leading to tuberculosis, anaemia, malnutrition being wiped out in hundreds of cases. In no other area in the country could a Socialist Health Committee have had greater scope for its activities and during the last six years under review we raised our health services to a standard not surpassed by any other comparable authority in Great Britain ${ }^{28}$.

Subsequent historical work has also praised the Labour council's municipal socialism and health service provision. Earwicker's study of the Labour Party and the creation of the NHS states that "in Sheffield, the fifth largest municipality in England, the Labour local authority spent many years building a first class health service"29. John Rowett has also stated that "Viennese experiments in municipal socialism had their British counterpart. A similar concern for the provision of social welfare and cultural facilities characterised Labour administration in the only British city under the party's control until [Glasgow and London in] 1933"30.

Ernest Rowlinson the Labour Leader of Sheffield City Council outlined the Sheffield Labour Council's notion of municipal socialism which "meant using the great municipal machine for the improvement of the city and to bring the greatest health, educational and cultural benefits to the people"31. However as we have seen earlier an analysis of the ideology of health care provision, throws light on a more complex picture. One where socialist ideology was at times a much less progressive influence on health policy than it has been previously portrayed. The anti-vaccination tendencies of the Chairman of the Health Committee in the 1920 s can be seen as, either a logical perception that better housing was the priority in order to reduce the rate of disease, or alternatively the views of Asbury could be seen as a negation of the realities of the problem, and an archaic, if not an anachronistic vision of a socialist utopia where disease would not exist. An examination of the services provided by this Labour local authority, also calls into question the reality of the socialist vision of the best health care being provided for the citizens of Sheffield.

${ }^{27}$ Sheffield Labour Party, Six Years of Labour Rule, Sheffield, 1932.

${ }^{28}$ Ibid.

${ }^{29}$ Ray EARWICKER, The Labour Movement and the Creation of the National Health Service, 1906-1948, (unpublished University of Birmingham Ph.D. thesis, 1982) p. 288.

${ }^{30}$ John ROWETT, The Labour Party and Local Government: Theory and Practice in the Inter-war

Years, (unpublished University of Oxford Ph.D. thesis 1979), p. 342.

${ }^{3 !}$ Ernest ROWLINSON, Six Years of Labour Rule, 1932. 


\section{Municipal socialism in action}

The degree of the council's commitment to house building and to building high quality housing cannot be questioned. Sheffield Council built 28000 dwellings in the inter-war years compared to 24000 built by the private sector. The national figure for the public sector in the period was 27.6 per cent, where Sheffield Council built 53.8 per cent of housing ${ }^{32}$. However evidence from the 1930s shows that although these greenfield housing estates were popular, there were significant drawbacks. Although the housing was of a good quality, the new estates lacked amenities, some of which were the product of a deliberate policy by the strong non-conformist teetotalist Methodist tradition among councillors. Many municipal housing estates were designed to be "dry", or free from Public Houses, and tenants were forced to become pro-active in order to lobby the council, to reverse this blatant paternalism. As a solution the council decided to hold a referendum on the nine largest of the new estates to gauge the strength of local opinion towards the inclusion of pubs ${ }^{33}$.

An independent social survey conducted in the 1930s showed that rather than be an entirely positive experience, the social realities of the new housing estates were problematic. Higher rents on the new estates, combined with their distance from the centre (which required the need to spend income on travel expenses), made them beyond the reach of the lowest paid workers. These factors had pushed some tenants to take in lodgers, therefore negating the idea that the new estates were an answer to overcrowding. Other tenants were reported as having to abandon the new estates altogether and return to less expensive, old inner city accommodation ${ }^{34}$. Besides pubs, other amenities lacking on the council estates were, libraries, markets, churches, parks, shops and in particular, health services. Until the late 1930s the local authority only provided one central maternity and child welfare clinic, in a city with a population of half a million. The council's critics on the left felt that the situation was a scandal. The Communist Party, condemned the council for its lack of health facilities for women ${ }^{35}$. The need for an expansion in maternity and child welfare services saw a second municipal clinic opened in $1936^{36}$. In terms of demand for services such as family planning,

${ }^{32}$ DICKENS et al., Housing, states and Localities 1985, p. 166.

${ }^{33}$ Andrew THORPE, The Consolidation of a Labour Stronghold: 1926-1951, in: Clyde BINFIFLD (ed.), The History of the City of Sheffield, Sheffield 1993, p. 103.

${ }^{34}$ A. D. K. OWEN, A Report on the Housing Problem in Sheffield, Sheffield Social Survey Committee, 1931.

${ }^{35}$ Communist Party Of Great Britain Sheffield Branch, Sheffield: The People's Policy for the City, Sheffield 1938.

${ }^{36}$ Sheffield Corporation, Firth Park Matemal and Child Welfare Centre: Opening Ceremony, Sheffield 1938. 
evidence from the records of a voluntary society the Sheffield Women's Welfare Clinic, shows that a clinic provided by the voluntary sector was heavily over subscribed by women from Sheffield and its region, and that the facilities available were unequal to the demand ${ }^{37}$.

A recent examination of maternity care in Sheffield in the late nineteenth and early twentieth century, by Tanya McIntosh has criticised both the public and voluntary sectors in Sheffield for failing to tackle the health needs of women. However where McIntosh denies that ideology had a role to play in this situation, I would argue that a combination of patriarchal attitudes and the prioritisation of certain services over others saw municipal socialist ideology contribute to the failure of localised health care to adequately provide for a large section of the city's population, i.e. women. McIntosh states that "both the Council and voluntary groups pursued policies that were based not on ideology but depended upon pragmatism and consensus ... the tone of all groups was pragmatic rather than ideological" 38 . McIntosh goes on to state that "the inter-war years in particular demonstrated conspicuous general levels of consensus over welfare developments and a lack of ideological debate"39.

While agreeing with McIntosh that explicit ideological debates between protagonists over the nature of health policy, are difficult to find, this paper has argued that a more nuanced handling of the concept of ideology can illustrate how ideology was a significant factor in the development, (or lack of development) of health services in Sheffield. The brand of municipal socialism espoused by the Labour Council in the 1920s led it to focus on housing, an area where the city built its reputation both as an employer and landlord. Also the anti-vaccinationism of the Chairman of the Health Committee, gives an indication of the ideological mindset of the council's municipal socialist thought towards health care and offers one explanation for the seeming lack of desire to provide adequate municipal health facilities in the city. The drive was therefore for wider municipal socialist policies such as the reconstruction of large parts of the city into healthy working class suburban estates, instead of the construction of clinics and welfare facilities.

By the 1930s there were strong signs that the municipal socialist vision of the council was evolving to incorporate the provision of health services. The Labour controlled City Council published a booklet in 1937 which detailed the entirety of the health services provided by the council so that "there should be a greater appreciation by the public of the value of health services which are placed at their

\footnotetext{
${ }^{37}$ Correspondence between Sheffield Women's Welfare Clinic and the National Birth Control Association. FPA A4/A 14.1, Contemporary Medical Archive Centre, Wellcome Institute for the History of Medicine, London.

${ }^{38}$ Tanya MCINTOSH, A Price Must be Paid for Motherhood: The Experience of Maternity in Sheffield, 1879-1939, (unpublished University of Sheffield Ph.D. thesis, 1997), p. 220.

${ }^{39}$ Ibid., p. 45.
} 
disposal ${ }^{40}$. The council emphasised how health services in the city were provided for citizens from the cradle, (maternity and child welfare services) to the grave (cremation). In between birth and death the local authority provided the school medical service, VD treatment, tuberculosis care, vaccination, the care of the mentally defective, smoke abatement, refuse collection and disposal, as well as public baths and public wash-houses. A major boost to the notion of a comprehensive municipal health service followed the Local Government Act of 1929 when permissive legislation enabled the City Council to develop its two former poor law hospitals to be run as general municipal hospitals, quite separate from poor relief arrangements. The City Council also introduced private legislation to the House of Commons, in an attempt to take over control of The West Riding Mental Hospital, which was physically within the city boundary and mainly treated patients from Sheffield, but was administered by an entirely separate level of local government, the West Riding County Council ${ }^{41}$.

Despite these local efforts towards establishing a comprehensive municipal health service in the 1930s, and despite 30 years of national Labour Party policy, the decision was taken by Aneurin Bevan, Minister of State for Health, in the 1946 NHS Act to nationalise rather than municipalise the National Health Service. A major element of pluralism, and any degree of urban democracy in health care provision, was lost. On the appointed day in 1948, local authorities lost control of all hospitals and most of their health functions. Legislation after the Second World War, produced in Britain one of the most centralised and bureaucratic welfare systems in Europe. Prior to this time welfare provision had been a highly localised affair reflecting the idiosyncrasies of both local voluntarism and the local state.

\section{Conclusion}

This paper has attempted to investigate the role of municipal socialism in the development of health policy in the city of Sheffield, in the inter-war years. Not only does a study of ideology highlight the different strategies of the Left and the Right over the appropriate level of municipalisation, it also enables us to comprehend a more nuanced understanding of the shape of health services provided in cities such as Sheffield under the banner of a municipal socialism. Civic leaders in Sheffield between the wars were genuinely concerned with both aspects of the

\footnotetext{
${ }^{40}$ Sheffield City Council Public Health Committee, The Public Health Services of the Sheffield City Council, Sheffield 1937.

${ }^{41}$ Sheffield City Archives SCA $5822 / 1$, Proofs of Evidence to House of Commons Committee, Sheffield Corporation Bill 1937.
} 
"municipal socialism" idea. Both its ideological and administrative elements. As a Labour stronghold, Sheffield has often been portrayed as an exemplar of municipal socialism, however whilst recognising that the 1930s saw health service provision as a key element of the Labour cause in Sheffield, events in the 1920s illustrate the more complex ways in which ideology informed service provision and the prioritisation of services. The paper has aimed to highlight ways in which the ideological basis of policy was expressed in words and deeds. Attitudes were expressed in newspapers and specialist journals, relating to the labour movement and socialism, as well as in professional health journals. However as the elected governors of the City from 1926, Labour in Sheffield expressed a pro-active form of municipal socialism in deeds through its desire to see the local state directly involved in the fields of health, education, housing and direct employment. In this way the theories and realities of municipal socialism were inextricably and concretely linked.

\section{Deutsche Zusammenfassung}

Der Beitrag behandelt den Munizipalsozialismus in der nordenglischen Industriestadt Sheffield während der Zwischenkriegszeit. Sheffield war 1926 die erste größere britische Stadt, die einen Labour-Stadrat wählte. Während bisherige Studien über den Munizipalsozialismus diesen als eine Form kommunaler Wirtschaftstätigkeit betrachtet haben, die wenig mehr als die Bereitstellung breiter öffentlicher Versorgung war, behandelt dieser Beitrag den Munizipalsozialismus als eine Ideologie von Sozialisten und Labour-Anhängern, die in der Lage waren, politische Ziele vorzugeben. Die Gesundheitsfürsorge dient als Fokus, um die sich entwickelnde Dynamik des Munizipalsozialismus sichtbar zu machen. Vor der Einfuihrung des National Health Service 1948 hatten die Kommunalverwaltungen in Großbritannien eine erheblich aktivere Rolle bei der Entwicklung und Bereitstellung medizinischer Dienste zu spielen. Der Beitrag untersucht, wie die Ideologie des Munizipalsozialismus die Meinungen lokaler Politiker prägte und zu einer aktiven ganzheitlichen Vorgehensweise für die Gesundheit und das Wohlergehen der Bürger führte. Es wird argumentiert, daß die 20er Jahre entscheidend für soziale Entwicklungen in der Stadt und die Konsolidierung der Labour-Basis in einer stark von der Arbeiterklasse geprägten Stadt waren. Munizipalsozialismus stellt sich als dynamische Ideologie dar, die sich im Verlauf der Zeit veränderte. Sheffield ist zu Recht als Beispiel eines Munizipalsozialismus in den Bereichen Wohnen und Beschäftigung angesehen worden, und die munizipalsozialistische Ideologie leistete ihren Beitrag bei der Prioritätensetzung für ganz bestimmte Dienstleistungen. Ein nuancierteres Verständnis der Beziehungen zwischen Ideologie und Politik beleuchtet indes auch Wege, auf denen der Munizipalsozialismus in die Übernahme weniger fortschrittlicher Einstellungen mündete, insbesondere bei solchen Fragen wie der Pockenschutzimpfung und der Bereitstellung von Mutterschaftsfürsorge.

\section{Résumé français}

Cet article examine le socialisme municipal durant l'entre-deux guerres dans une ville industrielle du nord de l'Angleterre, Sheffield. Sheffield était la plus importante des cités britanniques à avoir élu un conseil travailliste en 1926. Où d'autres études sur le socialisme municipal ont considéré 
le phénomène comme une forme de pratique municipale, l'administration des services publics à grande échelle, cet article considère le socialisme municipal comme une idéologie portée par des socialistes et des travaillistes qui étaient en position de faire passer leurs objectifs via la politique municipale. En ce sens le service de santé est une sorte de lentille à travers laquelle on peut voir la dynamique évolutive du socialisme municipal. Avant l'introduction du service de santé nationalisé en 1948, c'est le gouvernement local qui en Grande-Bretagne avait le rôle le plus actif d'administration et de développement des services de santé. Cet article examine les voies par lesquelles l'idéologie du socialisme municipal façonna l'état d'esprit des hommes politiques locaux et conduisit à une approche holiste et résolument active de la santé et du bienêtre des citoyens. L'article montre que les années 1920 furent une décennie cruciale en ce qui concerne la prise en compte des problèmes sociaux à l'échelle urbaine; que ce fut également la décennie de consolidation des assises du Parti travailliste dans une grande cité ouvrière. On s'aperçoit que le socialisme municipal est une idéologie dynamique en constante évolution. On montre que l'expérience de Sheffield a été précisément considérée comme celle du socialisme municipal exemplaire, notamment dans des domaines comme le logement et l'emploi. C'est précisément cette idéologie socialiste municipale qui désigne comme prioritaires certains types de services plutôt que d'autres. Toutefois, il faut nuancer la nature de la relation entre l'idéologie et certaines des politiques municipales mises en vedette, en particulier en matière de vaccination et de services de maternité. 
